\title{
Does the time between collecting and processing umbilical cord blood samples affect the quality of the sample?
}

\author{
0 intervalo de tempo entre coleta e processamento do sangue de cordão umbilical \\ influencia na qualidade da amostra?
}

\author{
Ricardo Barini ${ }^{1}$, Ubirajara Costa Ferraz², Gregório Lorenzo Acácio², Isabela Nelly Machado
}

\begin{abstract}
Objective: To assess the association between the time from umbilical cord blood collection until processing and the quality of the sample. Methods: Umbilical cord blood samples collected during the third stage of labor were placed in temperature-controlled boxes for the transport of biological material and sent to an umbilical cord blood bank, where the number of nucleated cells, viable cells and CD34+ cells were counted, and samples were additionally tested for contamination at the following time intervals: up to 24 hours, up to 48 hours and up to 72 hours following sampling. Data were analyzed using the multivariate analysis of variance (MANOVA) and compared using McNemar's $\chi^{2}$ test. Significance was defined at $p$ $<0.05$. Results: Means and medians of the number of nucleated cells, viable cells and CD34+ cells decreased significantly ( $p<$ 0.0001 ) as a function of the increased time between sampling and analysis, the difference between 24 and 48 hours being less than the difference between 24 and 72 hours. A linear correlation was found between the mean number of viable cells and CD34+ cells at the three moments of analysis. Contamination testing was negative in all samples. Conclusion: The increase in time interval from sampling until analysis negatively affected the number of nucleated cells, viable cells and CD34 + cells but was not associated with specimen contamination. A linear correlation was found between decrease in the number of viable cells and CD34+ cells.
\end{abstract}

Keywords: Adult stem cells; Fetal stem cells; Quality control; Umbilical cord; Fetal blood/transplantation

\section{RESUMO}

Objetivo: Avaliar a associação do intervalo de tempo entre coleta e processamento do sangue de cordão umbilical e a qualidade da amostra. Métodos: As amostras de sangue de cordão umbilical, colhidas no terceiro período do parto, foram acondicionadas em caixas homologadas para transporte de material biológico, com monitoração da temperatura, e enviadas a um banco de sangue de cordão umbilical, onde foram submetidas à contagem do número de células nucleadas, do número de células viáveis, do número de células CD $34+$ e pesquisa de contaminação, nos intervalos de tempo de até 24 , até 48 e até 72 horas. 0s dados foram analisados pelo teste de variância para medidas repetidas MANOVA e comparados por meio do teste do $\chi^{2}$ de Mc Nemar, considerando-se nível de significância de 5\%. Resultados: As médias e as medianas do número de células nucleadas, número de células viáveis e número de células CD34+ tiveram quedas significativas ( $p<0,0001$ ) com o aumento do intervalo de tempo de coleta/processamento, sendo entre 24 e 48 horas menor do que a comparação entre 24 e 72 horas. Constatada correlação linear entre as médias de células viáveis e células CD34+ nos três momentos da análise. A pesquisa de contaminação foi negativa em todas as amostras. Conclusão: 0 aumento do intervalo de tempo de coleta/processamento influenciou negativamente na contagem de células nucleadas, células viáveis e CD34 + e não esteve associado à contaminação das amostras. Foi constatada correlação linear entre a queda do número de células viáveis e de células CD34+.

Descritores: Células-tronco adultas; Células-tronco fetais; Controle de qualidade; Cordão umbilical; Sangue fetal/transplante

\section{INTRODUCTION}

In recent years, confirmation that adult stem cells (ASC) may transform themselves in other tissues stimulated many scientists to carry out studies in this area, since these cells may represent an alternative to the use of embryonic stem cells ${ }^{(1)}$. Umbilical cord blood (UCB), one of the principal sources of ASC, drew attention of scientists due to simplicity of sample collection, complete absence of risks to the mother or the newborn, reduced

\footnotetext{
Study carried out at Universidade de Taubaté - UNITAU, Taubaté (SP), Brazil.

' Universidade Estadual de Campinas - UNICAMP - Campinas (SP), Brazil.

2 Department of Medicine, Univesidade de Taubaté - UNITAU - Taubaté (SP), Brazil.

${ }^{3}$ College of Medical Science, Universidade Estadual de Campinas - UNICAMP - Campinas (SP), Brazil.

Corresponding author: Ricardo Barini - Rua Alexander Fleming, 101 - Cidade Universitária Zeferino Vaz - CEP 13083-902 - Campinas (SP), Brasil - Tel.: 193521 -9336 - e-mail: ricardo@barini.med.br

Received on: Jan 31, 2010 - Accepted on: Oct 11, 2010

Conflict of interest: none
} 
need for human leukocyte antigen (HLA) compatibility, lower risk of severe host-graft reaction and the lower risk of transmitting infectious and contagious diseases ${ }^{(2)}$. ASC may also be considered as an alternative to the use of bone marrow for treating several hematological, genetic and oncological diseases, both in children ${ }^{(2-4)}$ and in adults ${ }^{(5)}$.

Following the successful treatment of a case of Fanconi anemia with a UCB transplant ${ }^{(4)}$, extensive progress was made in research in this field, and umbilical cord blood banks (UCBB) were set up in Europe, Japan, China, United States and Brazil, as well as in other countries.

To enable a UCBB to serve as a supplier of donorrecipient compatible $\mathrm{UCB}$, approximately 12 thousand samples have to be stored to cover all the diverse racial characteristics and different ethnic origins that comprise a given population ${ }^{(6)}$, and these should ideally be obtained from different geographical regions. Since the UCB must be collected during the third stage of labor ${ }^{(2,7,8)}$, teams need to be trained to perform collections in locations that are geographically distant from the UCBB. In addition, bags must be shipped in temperature controlled boxes, suitable for transport of biological material, and samples must be sent for processing, thereby avoiding having to send patients to another city and making the storage of diversified samples economically viable ${ }^{(9)}$.

An interval of time exists between UCB collection at the hospital and the sample being processed at the $\mathrm{UCBB}$, and this period tends to increase as a function of the distance between the hospital and the blood bank. A review of the literature on this subject reveals contradictions with respect to the effects of this time interval, with some investigators reporting severe deterioration in quality tests after 9 hours and 24 hours, respectively, while others have reported satisfactory results up to 36 hours $^{(9-12)}$. In Brazil, the National Health Surveillance Agency (ANVISA), the health regulatory authority, determined that samples should be processed within 48 hours following collection ${ }^{(13)}$.

\section{OBJECTIVE}

The objective of the present study was to establish the effect of the time between collection at the maternity hospital and processing the samples at the UCBB on the quality of the UCB. The study also investigated the presence or absence of contamination, as well as the correlation between the number of viable cells and the number of CD34+ cells at the defined time intervals.

\section{METHODS}

A descriptive, prospective, observational study was carried out in 20 UCB samples from patients who had just delivered their babies and voluntarily agreed to participate in the study by signing the informed consent form. All patients fulfilled the inclusion criteria and none of the exclusion criteria. The protocol was approved by the Internal Review Board of the Faculdade de Ciências Médicas da Universidade Estadual de Campinas (UNICAMP).

The inclusion criteria comprised age $>18$ years; gestational age $\geq 35$ weeks; fetal weight $\geq 2,000 \mathrm{~g}$; amniorrhexis less than 18 hours previously; and absence of infectious processes during pregnancy or diseases that could interfere with placental vitality. The exclusion criteria consisted of severe fetal distress (meconium over ++ and 1-minute Apgar $<5$ ) and infection during labor (abnormalities in the color or odor of the amniotic fluid and maternal temperature $>38^{\circ} \mathrm{C}$ during labor).

The decree RDC 153 of the Brazilian health regulatory authority states that the total number of nucleated cells should be at least $5 \times 10^{8}$ and the volume of the UCB sample collected should be at least 70 $\mathrm{mL}^{(13)}$. In the present study, these requirements were not considered exclusion factors since the bags were discarded after performing the quality control tests.

UCB samples were collected at the maternity unit of the teaching hospital at Faculdade de Medicina da Universidade de Taubaté (UNITAU), State of São Paulo, Brazil, during the third stage of labor, after delivery and cord clamping and prior to placental detachment, following asepsis of a segment of the cord and puncture of the umbilical vein, using a top-and-bottom bag system (Optipress ${ }^{\circledR}$, Baxter Healthcare).

After collection, the bag containing the UCB was stored in a temperature-controlled box containing two 400-gram units of recyclable ice, in accordance with the International Air Transport Association (IATA) ${ }^{(14)}$ specifications for the transport of biological material for diagnosis. Temperature was electronically monitored using the Kooltrak ${ }^{\circledR}$ system (Dallas Technologies) ${ }^{(15)}$ and the computerized CB Bank Manager ${ }^{\circledR}$ reading system. The samples were transported by road to the UCBB Criogênesis, in the city of São Paulo, Brazil. Since the two cities are $150 \mathrm{~km}$ apart, the time interval between collection and arrival of the samples at the UCBB was estimated to be less than 24 hours.

In the UCBB, the bags were kept in the temperaturecontrolled boxes and temperature was continuously monitored. The boxes were opened quickly at the following time intervals: up to 24 hours, up to 48 hours and up to 72 hours following collection, and $3 \mathrm{~mL}$ of UCB were removed using a sampling cannula. The samples were submitted to the most commonly used quality control tests, which included nucleated cell count, 
viable cell count (without rupture of cell membrane) and CD34+ cell count (CD34 being expressed in hematopoietic stem cells $)^{(2,3,5,8-11,16-19)}$.

Nucleated cell count was performed in a Neubauer counting chamber. Viable cells were counted by excluding cells stained by $0.4 \%$ trypan blue (SigmaAldrich, USA). The total number of viable cells was calculated from the percentage of viable cells multiplied by the number of nucleated cells. CD34+ cell count was performed using the commercial CD34 reagent (ProCOUNT ${ }^{\circledR}$, Becton-Dickinson, San Jose, California, USA) and reading was carried out using flow cytometry (FacsCalibur $^{\circledR}$, Becton-Dickinson, San Jose, California, USA). The total number of CD34+ cells was calculated from the percentage of CD34+ cells multiplied by the number of nucleated cells.

The presence of contamination was investigated using the pediatric BacT/ALERT ${ }^{\circledR}$ (Biomérieux) blood culture system ${ }^{(20)}$, one for aerobic agents and another for anaerobic agents. This method allows identification of contamination not specifying the bacterial agent.

Data were analyzed using multiple analyses of variance (MANOVA) and compared using McNemar's $\chi^{2}$ test, considering a significance level of $5 \%$.

\section{RESULTS}

All 20 boxes containing bags of UCB samples arrived at the UCBB within 24 hours of collection. The volume of the bags varied between 31 and $139.4 \mathrm{~mL}$ (mean: $80.6 \pm 31.7 \mathrm{~mL}$; median: $72.5 \mathrm{~mL}$ ). The total number of nucleated cells ranged from 206 million to 3.4 billion, with a mean of 1.1 billion in the first 24 hours, decreasing to a mean of 1.03 billion at 48 hours, and 841 million at 72 hours, differences that were statistically significant $(\mathrm{p}<0.0001)($ Table 1$)$.
The number of viable cells varied from 202 million to 3.3 billion with a mean of 1.1 billion in the first 24 hours, decreasing progressively to a mean of 967 million at 48 hours and 711 million at 72 hours, differences that were also statistically significant ( $<<0.0001)$ (Table 1$)$.

The number of CD34+ cells ranged from 672 thousand to 23 million with a mean of 6.3 million in the first 24 hours, decreasing progressively to a mean of 5.5 million at 48 hours and 4 million at 72 hours, differences that were statistically significant $(\mathrm{p}<0.0001)$ (Table 1$)$. Comparison of the means at 24 and 48 hours showed a smaller but still statistically significant decrease compared to the difference in the means at 24 and 72 hours (Figure 1). As the variation between the minimum and maximum number of nucleated cells in the samples was very large, the median percentage variation was also calculated and these comparisons were also statistically significant (Table 2).

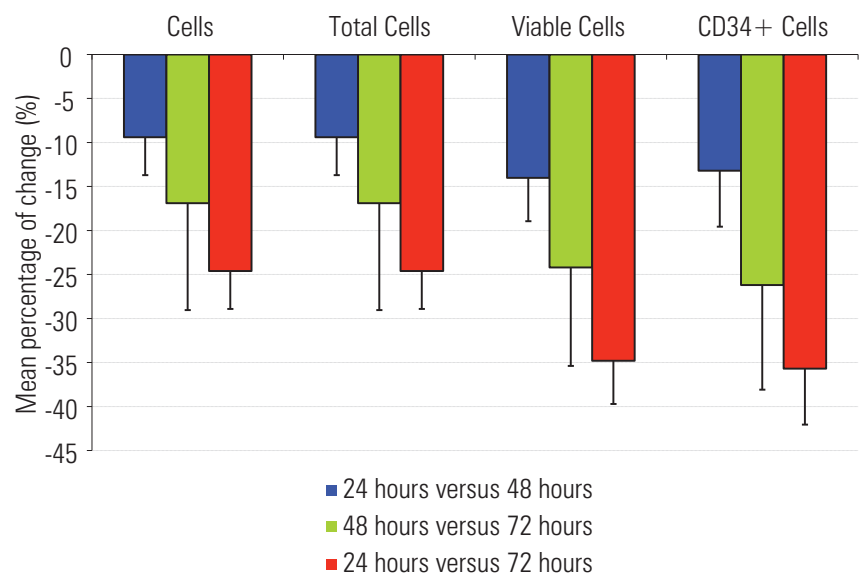

Figure 1. Variation in the mean percentage of number of nucleated cells, viable cells and CD34+ cells in UCB bags between the following time intervals: 24 versus 48 hours, 48 versus 72 hours and 24 versus 72 hours (95\%Cl)

Table 1. Blood volume, variation in number of nucleated cells, viable cells and CD34+ cells at intervals of time of up to 24 hours, up to 48 hours and up to 72 hours in bags of umbilical cord blood (UCB)

\begin{tabular}{|c|c|c|c|c|c|c|}
\hline Bags of UCB & $\mathbf{n}$ & Mean & Standard deviation & Median & Minimum & Maximum \\
\hline Volume collected (mL) & 20 & 80.6 & 31.7 & 72.5 & 31 & 139.4 \\
\hline \multicolumn{7}{|l|}{ Nucleated cells } \\
\hline Up to 24 hours & 20 & $11 \times 108$ & $9.0 \times 108$ & $7.9 \times 108$ & $2.0 \times 108$ & $34 \times 108$ \\
\hline Up to 48 hours & 20 & $10 \times 108$ & $7.9 \times 108$ & $7.2 \times 108$ & $1.8 \times 108$ & $29 \times 108$ \\
\hline Up to 72 hours & 20 & $8.4 \times 108$ & $5.9 \times 108$ & $6.3 \times 108$ & $1.4 \times 108$ & $19 \times 108$ \\
\hline \multicolumn{7}{|l|}{ Viable cells } \\
\hline Up to 72 hours & 20 & $7.1 \times 108$ & $5.0 \times 108$ & $5.3 \times 108$ & $1.2 \times 108$ & $16 \times 108$ \\
\hline \multicolumn{7}{|l|}{ CD34+ cells } \\
\hline Up to 24 hours & 20 & $6.3 \times 106$ & $6.3 \times 106$ & $4.3 \times 106$ & $0.6 \times 106$ & $23 \times 106$ \\
\hline Up to 48 hours & 20 & $5.5 \times 106$ & $5.4 \times 106$ & $3.7 \times 106$ & $0.5 \times 106$ & $19 \times 106$ \\
\hline Up to 72 hours & 20 & $4.0 \times 106$ & $3.7 \times 106$ & $3.1 \times 106$ & $0.3 \times 106$ & $12 \times 106$ \\
\hline
\end{tabular}


Table 2. Variation in the median percentage of number of nucleated cells, viable cells and CD34+ cells in the UCB bags between the time intervals of 24 versus 48 hours, 48 versus 72 hours and 24 versus 72 hours

\begin{tabular}{|c|c|c|c|c|}
\hline Parameter & Median & 1st quartile & 3rd quartile & p-value* \\
\hline \multicolumn{5}{|l|}{ Nucleated cells } \\
\hline 24 hours versus 48 hours & -8.3 & -12.0 & -6.1 & $<0.0001$ \\
\hline 48 hours versus 72 hours & -13.5 & -17.8 & -9.3 & $<0.0001$ \\
\hline 24 hours versus 72 hours & -20.5 & -26.6 & -17.6 & $<0.0001$ \\
\hline \multicolumn{5}{|l|}{ Viable cells } \\
\hline 24 hours versus 48 hours & -13.0 & -17.3 & -11.4 & $<0.0001$ \\
\hline 48 hours versus 72 hours & -22.8 & -28.0 & -16.7 & $<0.0001$ \\
\hline 24 hours versus 72 hours & -32.6 & -37.9 & -26.3 & $<0.0001$ \\
\hline \multicolumn{5}{|l|}{ CD34 + cells } \\
\hline 24 hours versus 48 hours & -12.1 & -16.9 & -8.0 & $<0.0001$ \\
\hline 48 hours versus 72 hours & -23.9 & -30.4 & -18.2 & $<0.0001$ \\
\hline 24 hours versus 72 hours & -30.2 & -42.6 & -27.0 & $<0.0001$ \\
\hline
\end{tabular}

* The p-value was obtained using the Wilcoxon test for paired values.

The variations in the number of viable cells and CD34+ cells were compared and a linear correlation was found between the three moments of analysis (up to 24 hours, up to 48 hours and up to 72 hours) (Table 3 ).

Table 3. Correlation between the variations in number of viable cells and CD34+ cells at the following time intervals: up to 24 hours, up to 48 hours and up to 72 hours

\begin{tabular}{lcc}
\hline Interval of time & $\mathbf{r}^{*}$ & p-value \\
\hline Up to 24 hours & 0.86 & $<0.0001$ \\
Up to 48 hours & 0.83 & $<0.0002$ \\
Up to 72 hours & 0.85 & $<0.0003$ \\
\hline
\end{tabular}

* Spearman's rank correlation coefficient.

\section{DISCUSSION}

Confirmation of the usefulness of adult stem cells in the treatment of hematological diseases opened the gateway to further research into the different sources of obtaining these cells. One source that has grown in importance is UCB, since collection is simple and poses no risk to the donor. In addition, it requires a lesser degree of HLA donor-recipient compatibility compared to bone marrow, for example.

In Brazil, the large geographical area of the country and the ethnical diversity of its population may limit the use of UCB due to the difficulty in identifying a compatible donor, despite knowing that the chance of a Brazilian finding a donor in the country is 30 times greater than the chance of finding a compatible donor abroad, according to a study carried out by the National Registry of Bone Marrow Donors (Registro Nacional de Doadores de Medula Óssea - REDOME)(21).

Of approximately 3,000 patients referred annually for bone marrow transplant, 1,700 are unsuccessful in identifying a compatible donor among relatives, and are obliged to resort to the waiting list in which the average delay in identifying a compatible donor is six months ${ }^{(21)}$. To facilitate identification of a compatible donor and to reduce waiting time, great interest is currently being shown in ensuring that UCBBs be able to store a sufficient number of samples originating from different geographical regions of the country.

A public UCBB with 12 thousand samples in stock guarantees identification of a compatible sample in practically $100 \%$ of cases, and the waiting time can be reduced to 20 days. In addition, a great reduction in costs may be achieved, since to collect and store a UCB sample in Brazil costs around $\mathrm{R} \$ 3,000.00$, as compared to a cost of about $R \$ 96,000.00$ if the sample were to be obtained abroad ${ }^{(21)}$.

In agreement with data published in the literature, the present study shows that the quality of UCB deteriorates as a function of the length of time between collection and processing at blood banks ${ }^{(9-12)}$. In Brazil, the decree RDC 190/2003 issued by ANVISA requires UCB samples to be processed within 36 hours following collection; however, the decree RDC 153/2004 extended this interval to up to 48 hours. In the international studies reviewed, the majority establishes criteria of 24 or 36 hours as the upper limit for accepting samples for processing.

Based on the findings of this small sample, it is impossible to either corroborate or refute the limits established by the ANVISA. Although the decrease in the number of nucleated cells, viable cells and CD34+ cells was evident, no precise cut-off point was established. It is clear, however, that the interval between collection and processing should be the minimum possible.

In the present study, no contamination of the samples occurred due to increased time interval between collection and processing, probably because all samples were collected by the same investigator and rigorous asepsis criteria were adopted.

In addition, a linear correlation was found between the variation in the mean percentage of the number of viable cells and CD34+ cells. When the variation in median percentage was calculated, a greater increase was observed in the variation of the viable cells in relation to the $\mathrm{CD} 34+$ cells in the interval between 24 and 72 hours. These results are compatible with findings reported in the literature ${ }^{(9)}$. Confirmation of the existence of this correlation is important, since cell viability is measured more easily and at a lower cost than CD34+ cell count.

\section{CONCLUSION}

These findings confirm that an increase in the time interval between collection and processing negatively 
affects the quality of the UCB sample and this should encourage performance of further studies with larger sample sizes that are required to confirm the present results. These data may be useful for establishing national policies to define the geographical location of UCBBs, allowing samples to be collected from geographically diverse populations while guaranteeing rapid processing and freezing, thereby preserving the quality of samples and increasing the likelihood of identifying donor-recipient compatible samples.

\section{ACKNOWLEDGMENTS}

The authors would like to acknowledge the collaboration of Criogênesis Serviços Médicos S/C Ltda., specifically the director of the company, Doctor Nelson Hidekazu, who played an essential role in making this study feasible.

\section{REFERENCES}

1. Kuehnle I, Goodell MA. The therapeutic potential of stem cells from adults. BMJ. 2002;325(7360):372-6.

2. Fasouliotis SJ, Schenker JG. Human umbilical cord blood banking and transplantation: a state of the art. Eur J Obstet Gynecol Reprod Biol. 2000;90(1):13-25.

3. Smith FO, Thomson BG. Umbilical cord blood collection, banking, and transplantation: current status and issues relevant to perinatal caregivers. Birth. 2000;27(2):127-35.

4. Gluckman E, Rocha V. History of the clinical use of umbilical cord blood hematopoietic cells. Cytotherapy. 2005;7(3):219-27.

5. U-pratya Y, Boonmoh S, Promsuwicha O, Theerapitayanon C, Kalanchai L, Chanjerboon V, et al. Collection and processing of umbilical cord blood for cryopreservation. J Med Assoc Thai. 2003;86(11):1055-62.

6. Brasil. Ministério da Saúde. Instituto Nacional de Câncer (INCA) [Internet]. Secretaria de Atenção à Saúde. [citado 2011 Abr. 16] Disponível em: http:// www.inca.gov.br.

7. Gluckman E. Current status of umbilical cord blood hematopoietic stem cell transplantation. Exp Hematol. 2000;28(11):1197-205.
8. Surbek DV, Visca E, Steinmann C, Tichelli A, Schatt S, Hahn S, et al. Umbilical cord blood collection before placental delivery during cesarean delivery increases cord blood volume and nucleated cell number available for transplantation. Am J Obstet Gynecol. 2000;183(1):218-21.

9. Wada RK, Bradford A, Moogk M, Yim R, Strong DM, Drachman J, et al. Cord blood units collected at a remote site: a collaborative endeavor to collect umbilical cord blood through the Hawaii Cord Blood Bank and store the units at the Puget Sound Blood Center. Transfusion. 2004;44(1):111-8.

10. Shlebak AA, Marley SB, Roberts IA, Davidson RJ, Goldman JM, Gordon MY. Optimal timing for processing and cryopreservation of umbilical cord haematopoietic stem cells for clinical transplantation. Bone Marrow Transplant. 1999;23(2):131-6.

11. Tsagias N, Kouzi-Koliakos K, Karagiannis V, Alamdar DH, Koliakos G. Time and temperature before processing influence the recovery of umbilical cord blood hematopoietic progenitors. Transfusion. 2007:47(8):1550-2.

12. Antonenas V, Garvin F, Webb M, Sartor M, Bradstock KF, Gottlieb D. Fresh PBSC harvests, but not BM, show temperature-related loss of CD34 viability during storage and transport. Cytotherapy. 2006;8(2):158-65.

13. Agência Nacional de Vigilância Sanitária (ANVISA). Resolução RDC $n^{0} 153$, de 14 de junho de 2004. Brasília (DF): DOU, 2004

14. International Air Transport Association (IATA) [Internet]. [cited 2011 Apr. 16] Available from: www.iata.org

15. Kooltrak ${ }^{\circledR}$ - Dallas Technologies ${ }^{\circledR}$ [Internet]. Information about Kooltrak ${ }^{\circledR}$ temperature recording [cited 2011 Apr. 16]. Available from: www.kooltrak. com/data-loggers-v/sysint.html

16. Campos L, Roubi N, Guyotat D. Definition of optimal conditions for collection and cryopreservation of umbilical cord hematopoietic cells. Cryobiology. 1995;32(6):511- 5 .

17. Hubel A, Carlquist D, Clay M, McCullough J. Short-term liquid storage of umbilical cord blood. Transfusion. 2003;43(5):626-32.

18. Chao NJ, Emerson SG, Weinberg KI. Stem cell transplantation (cord blood transplants). Hematology Am Soc Hematol Educ Program. 2004;354-71.

19. Rodríguez L, García J, Querol S. Predictive utility of the attached segment in the quality control of a cord blood graft. Biol Blood Marrow Transplant. 2005;11(4):247-51.

20. bioMerieux Industry Industry-- BacT/ALERT 3D [Internet]. Available from: www.biomerieux-usa.com/clinical/microbiology/bact alert3d

21. Brasil. Ministério da Saúde. Instituto Nacional de Câncer (INCA) [Internet]. Registro Nacional de Doadores de Medula Óssea (REDOME) [citado 2011 Abr. 16]. Disponível em: http://www.inca.gov.br/conteudo view. asp?!D $=677$ 